\title{
THE POSSIBILITY FOR PUBLIC GREEN OPEN SPACE PROVISION IN INFORMAL SETTLEMENT CASE STUDY OF KAMPUNG KEJAWAN LOR, SURABAYA
}

\author{
Shirleyana*, Astri Anindya Sari** \\ *) Lecturer, Department of Architecture, Widya Kartika University, Surabaya, Indo- \\ nesia \\ **) Lecturer, Department of Architecture, Widya Kartika University, Surabaya, In- \\ donesia \\ e-mail: shirleyana@widyakartika.ac.id
}

\begin{abstract}
Green open space has been a worldwide issue. Big cities in the world have a higher concerns regarding open space provision. Researchers have proven that open space will improve the quality of life of people. However, problems of green space provision are also arising related to scarcity of land which is a common problem to cities with high density of population. One solution offered in big cities is converting vacant lot into pocket park. However, this solution could be different for informal settlement. The problems are worsened in this higher density area. The limited space and no proper infrastructure induce big problems such as health and social problems. This paper would like to find out the possibility to create such pocket park in the very limited space of informal settlement. The case study area looked at the informal settlements in coastal area in Surabaya, which is supposed to build the city image as waterfront city. The situation in the settlement has decreased over years and need a revitalization effort. This study used literature review to find solution of problems derived from the field observation. Pocket park could be an alternative solution which includes three successful factors: community participation, local identity, and support from community organization and government.
\end{abstract}

Keywords: green space, informal settlement, pocket park, quality of life

\section{ABSTRAK}

Ruang terbuka hijau telah menjadi isu di seluruh dunia. Kota-kota besar di dunia memiliki kekhawatiran tinggi tentang penyediaan ruang terbuka. Para peneliti telah membuktikan bahwa ruang terbuka akan meningkatkan kualitas hidup masyarakat. Namun, masalah penyediaan RTH juga timbul terkait dengan kelangkaan tanah yang merupakan masalah umum untuk kota-kota dengan kepadatan populasi yang tinggi. Salah satu solusi yang ditawarkan di kota-kota besar adalah mengubah tanah kosong menjadi taman saku. Namun, solusi ini dapat berbeda untuk 
penyelesaian informal. Masalah yang memburuk di daerah kepadatan tinggi ini. Keterbatasan ruang dan tidak ada infrastruktur yang tepat mengakibatkan masalah besar seperti masalah kesehatan dan sosial. Melalui tulisan ini, peneliti ingin mengetahui kemungkinan untuk membuat taman saku tersebut dalam ruang yang sangat terbatas dari permukiman informal. Daerah studi kasus memandang permukiman informal di daerah pesisir di Surabaya, yang seharusnya untuk membangun citra kota sebagai waterfront city. Situasi pemukiman telah menurun selama bertahun-tahun dan perlu upaya revitalisasi. Penelitian ini menggunakan kajian literatur untuk mencari solusi dari masalah yang berasal dari observasi lapangan. Taman saku bisa menjadi solusi alternatif yang mencakup tiga faktor sukses: partisipasi masyarakat, identitas lokal, dan dukungan dari organisasi masyarakat dan pemerintah.

Kata kunci: ruang hijau, permukiman informal, taman saku, kualitas hidup

\section{INTRODUCTION}

The need for green public open space has been a major issue in the world. Lerner (2003) mentioned that the existence of public open space as a means of community activities can bring the city to life which ultimately will improve the quality of the urban environment and life in society.

Recognizing its importance, the Government of Surabaya city has started to promote the program of green open space expansion in the recent years. Provision of good quality of green open spaces was performed by improving public space management, planning for new urban park, as well as enforcing temporary public open space through car free day program every week. These efforts have contributed to the increasing amount of green open spaces in Surabaya. However, the provision of green open spaces in highly dense settlements is still the biggest challenge for the municipality to improve the quality of life of the citizens.

Availability of public open space in residential areas is an absolute necessity to leave space for the community activity. Nevertheless, in highly dense settlement, the availability of vacant land to be used as a common space has often become the problem to provide appropriate public space for the community.

This study aims to explore the possibilities for the provision of qualified public open space in highly dense residential area in the city. The study selects Kampung Kejawan Lor in Kenjeran district, as the study area. Kampung Kejawan Lor is one of the coastal settlements in the eastern part of Surabaya which is densely populated and considered as an informal fishing settlement. The results of this research are expected to be a practical solution for the provision of public green open space which can improve the quality of the built environment and the quality of life of the community. It is considered very important because the presence of a fishing village with good environmental quality and distinctive community activities will strengthen the image of Surabaya as waterfront and coastal city.

The research method used in this study is field observations and spatial analysis to map the physical, social, and environmental problems that exist in the study 
area. Literature review eventually facilitates in seeking proposed solution from the issues raised in the case study area.

\section{THEORY / RESEARCH METHODS}

\section{The Need for Green Space}

Urbanization is present in the worldwide, and it is considered as continuous process. It is a logical result when people move towards a better life and society (Kirmanto et al, 2012). In the developing countries, UN has expected that 80 per cent of the world demography reside in urban areas in 2030 (Beardsley et al, 2009 in S. Gairola and Noresah, 2010). Thus, the world needs to maintain equilibrium balance between socioeconomic and environmental conditions, to minimize the urban development impact on the natural environment (Barredo and Demicheli, 2003 in S. Gairola and Noresah, 2010).

In Indonesia case, there were more than 112 million people living in the urban areas, reaching 52,03 per cent of total Indonesian population (Kirmanto, et al, 2012). The capital city, Jakarta, is ranked as $24^{\text {th }}$ place for world's biggest metropolitan. The urbanization has resulted in multiplication of urban issues, congestion, and green space elimination. The phenomenon of urban sprawling is not only happened in Jakarta and its periphery, but also in other Indonesian big cities such as Surabaya, Bandung, and Medan. The Indonesian big cities are now suffering the lost of green spaces. In these big cities, green open space has decreased from 35 percent into less than 10 percent. The green open space area is only around 7,08 $\mathrm{m} 2$ per capita in Jakarta. This is very low compared to other big cities in developed countries suchlike Stockholm with $80 \mathrm{~m} 2$, Berlin with about $30 \mathrm{~m} 2$, and Paris about $15 \mathrm{~m} 2$.

Gill et al (2007) in S. Gairola and Noresah, 2010, has emphasized the importance of green space for cities on climate. Urban green spaces play significance role for future generation, since they provide ecological services, protecting cities from climate change effects. Kuo, F.E. (2010) has done research in benefits of nature to human physical and mental health. The studies found that greater access to nature, green views and environments brings healthier physical life, mental life, as well as social function. This means the green environments are not only benefiting individual life, but also building stronger social ties within neighborhood, more social interaction, hence less violence and crime.

Considering the need for green space, Indonesia has taken into consideration concept of green city to cope with the problems of urban sprawl (Kirmanto, et al, 2012). The Ministry of Public Work launched a program called Green City Development Program (GCDP) in 2011. They formulated Green City attributes as: green planning and design, green community, green open space, green water, green waste, green energy, green transportation, and green building. One of the attributes is green open space, which has been campaigned and transformed into various community activities such as Indonesia Berkebun. However, Indonesian citizens cannot rely on instant efforts, but need a continuous learning power to empower the community to realize the importance of green space. 


\section{Community Stories of Developing Green and Public Spaces}

\section{Kampung Kali Code Yogyakarta}

Kampung Kali Code, located on the riverbank of Yogyakarta, is one of the informal settlements which eventually succeeded in increasing amount of greeneries for its settlement. As well as other informal settlements problems, Kampung Kali Code also had similar issues of availability of land and poor economic conditions. The kampung dwellers tried to overcome the poor conditions using the strategy for planting system, in accordance with the existing conditions (Felasari, 2005).

To overcome the scarcity of land problem, the community used pots and hanging pots as a medium for plantation (see Figure 1). Plantation is placed in front of the individual houses as well as in common spaces such as the riverbank retaining wall. The existence of these plants creates a fresh and green ambience within the neighborhood.
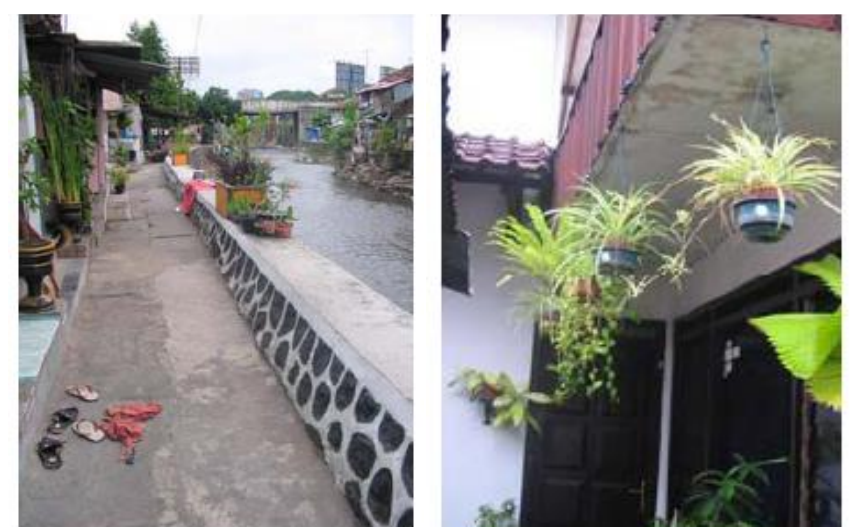

Figure 1. Pots are Used as A Plantation Media Source: Felasari, 2005

Lack of financial capability is anticipated by selecting types of plants that not only green but also add an economic value that can be utilized by the community. This method is known as an urban farming. The plants categories for this farming method are: medicinal plants like ginger, fruits and vegetables (Felasari, 2005).

Urban farming method has been implemented in big cities in Indonesia, suchlike Jakarta and Bandung (see Figure 2). These activities are considered to bring many benefits in terms of economic factor and social factor. The community can also learn how to manage the local farming within their neighborhoods (Santoso, 2012). Social cohesion will also turn out as a result of common activities. The perceived benefits are expected as a motivating factor. Hence the urban farming activities could take place on an ongoing basis. 


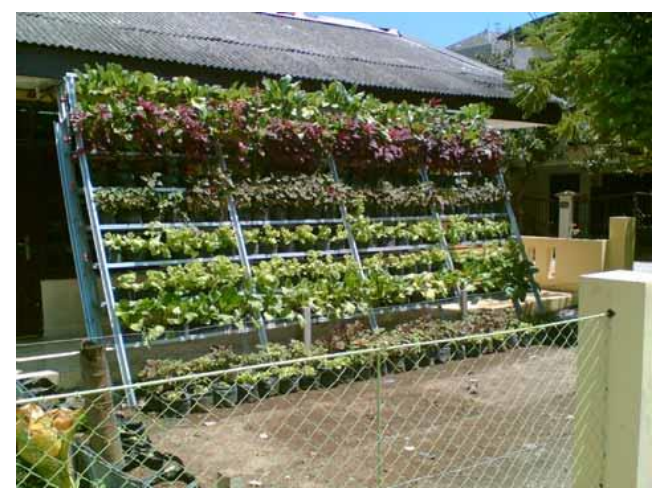

Figure 2. Vertical Urban Farming Functions as A Green Wall Source: Santoso, 2012

\section{Estonoesunsolar-Zaragosa, Spain}

'Estonoesunsolar' literally means this is not a vacant lot, is the provision of public open space strategy in Zaragosa. The public open space provision is done by converting existing vacant lot into a temporary living public space (see Figure 3) (Di Monte \& Gravalos, 2011).

The implementation of the program involved the Zaragosa Government as the initiator, the planning team, and the local community. In practice, the local people participated both in idea contribution and implementation of public space that suit their needs. The success of this project ultimately spread out throughout the city. There were some number of vacant lots that have been successfully converted into a children's playgrounds, basketball courts, urban gardens and squares, and they became a lively place and are well utilized by the community. The successful factor of this project is mainly due to good communication and cooperation between the government and the community. Direct community involvement from the beginning of the project, implementation and utilization foster a sense of ownership for the temporary created public open space. Sense of ownership and community participation are essential elements to achieve sustainable development.
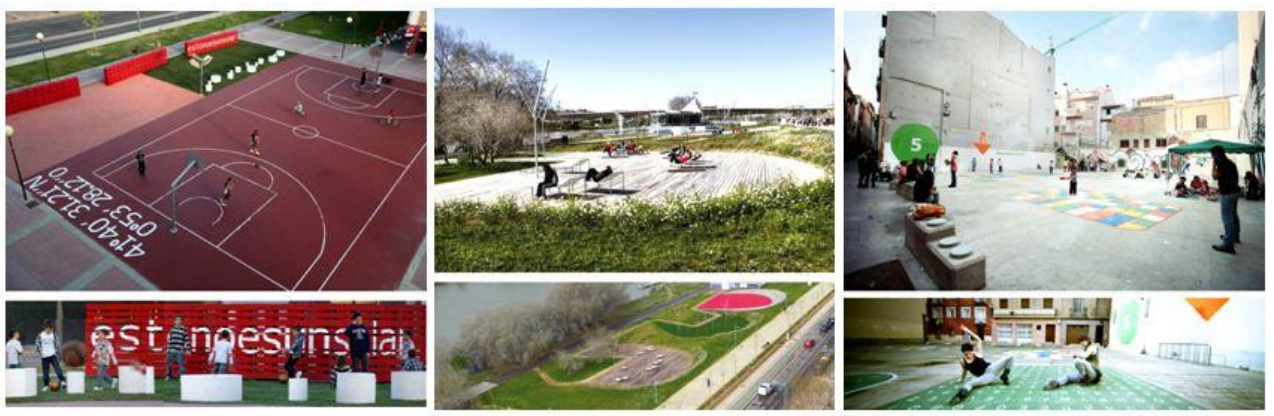

Figure 3. Optimizing Vacant Lot in Estonosunsolar-Zaragosa, Spain Source: http://www.underconstructions.eu/estonoesunsolar-spain-2 i/ in Sari and Shirleyana, 2012) 


\title{
Getting Innovative with Pocket Park
}

One way to increase green space area in available environment is to convert leftover spaces and other urban eyesore into pocket park. Many community groups created pocket parks to demonstrate their efforts in organizing more open space within their neighborhood (National Recreation and Park Association, 2013).

\begin{abstract}
"The new landscapes that began to spring up in their hundreds throughout the cities towards the end of the decade were small-scale, made by volunteers or 'amateurs', often expressing some highly idiosyncratic genius loci. They were called by different names: pocket parks, nature parks, community or neighbourhood gardens (NicholsonLord, 1987)."
\end{abstract}

This unique urban space is often created on vacant lots, rooftop and other forgotten spaces. Pocket park can be place to facilitate recreation, play areas for children, spaces for social interaction, thus it tend to act as a small scale neighborhood park (Blake, 2013). Some examples of pocket parks are even accessible to public, not only for the neighborhood. The initiative of the parks can come out from the community with the support from local community organization and local government. However, the place should have local identity, uniqueness and provoke positive social function. Otherwise, the place will return to former situation, a forgotten space (Shirleyana, 2013).

Pocket park does not only treat the abandoned space, but it also empowers the community to maintain their neighborhood. They can use recycled things from the streets or within the neighborhood and change what supposed to be garbage into useful and valuable thing (Atenistas, 2013).

\section{Research methods}

Taking into account the way pocket park could be delivered and the positive impacts for the community, it is the time to seek ways of how the pocket park could be implemented in the blighted area of urban informal settlements.

This study undertook mainly in qualitative research. The study used literature review, direct observations and a range of interviews. Literature study is needed to give background and necessity of public green open space and to study the ways community develop green open space within their neighborhood. The case study is selected as one example of problems, to search for the possibilities for public green open space provision. Direct observations were conducted to evaluate green open space provision and the physical, social, and environmental problems that exist in the study area. Interviews with local residents were done to fill the information gap. The spatial observations were processed using descriptive analysis. Some successful case studies are reviewed in seeking proposed solution from the issues raised in the case study area. 


\section{RESULTS AND DISCUSSION}

\section{Case Study Area: Kampung Kejawan Lor}

\section{Location and Characteristics}

Kampung Kejawan Lor, the study area, is a densely populated settlements located on the eastern coastline of Surabaya. Its location is directly adjacent to Kenjeran Beach in Madura Strait and has great marine potential. Most of Kampung Kejawan Lor dwellers depend on the marine products for their livelihoods. They work as fishermen, fisher laborers, fish sellers, fish crackers makers (Arifin et.al, 2012).

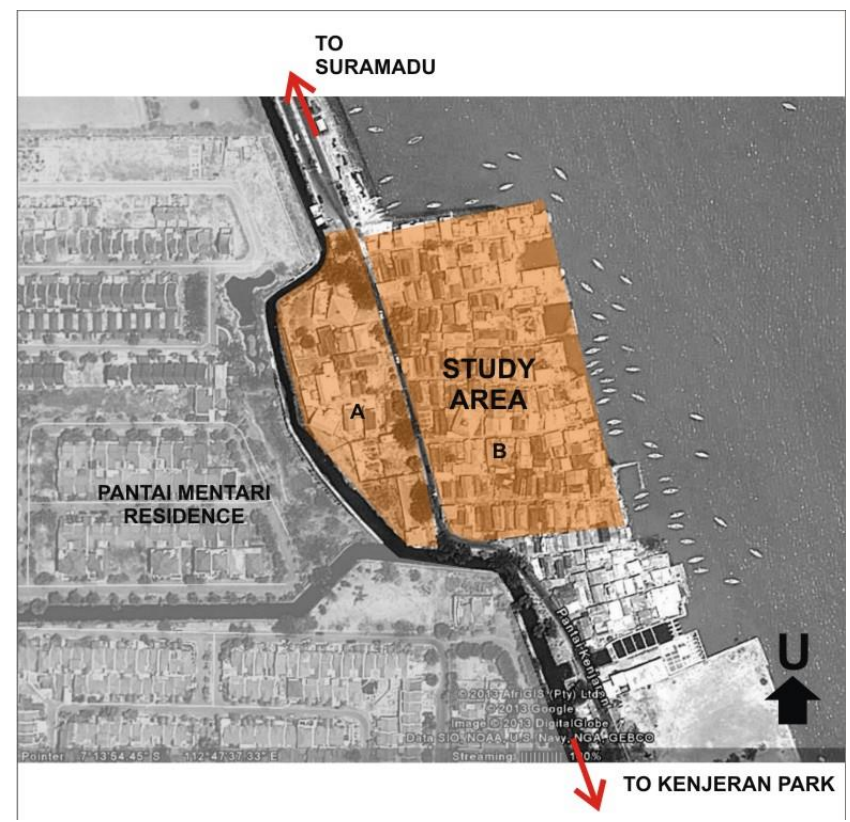

Figure 4. Location of Case Study Area

Source: modified from Google Map 2013.

Kampung Kejawan Lor is divided into two areas (see Figure 4), separated by 5 meter street wide. Area A consists of settlement area and public facilities such as community center, musholla, and public toilet room. Area B comprises of more dense settlement and located next to the sea. The study focuses on the problems occur in area B.

Houses in Kampung Kejawan Lor are connected by narrow pathways directly to the main street (see Figure 5). The 1.5 meters wide pathway physically serves not only for circulation, but also functions as a common space for social interaction, relaxing, and doing activities to support their livelihood like cleaning and drying fishes. The usage of circulation area is mainly cause by no other options for shared place for the community (see Figure 6). Almost all of available lots are occupied. 


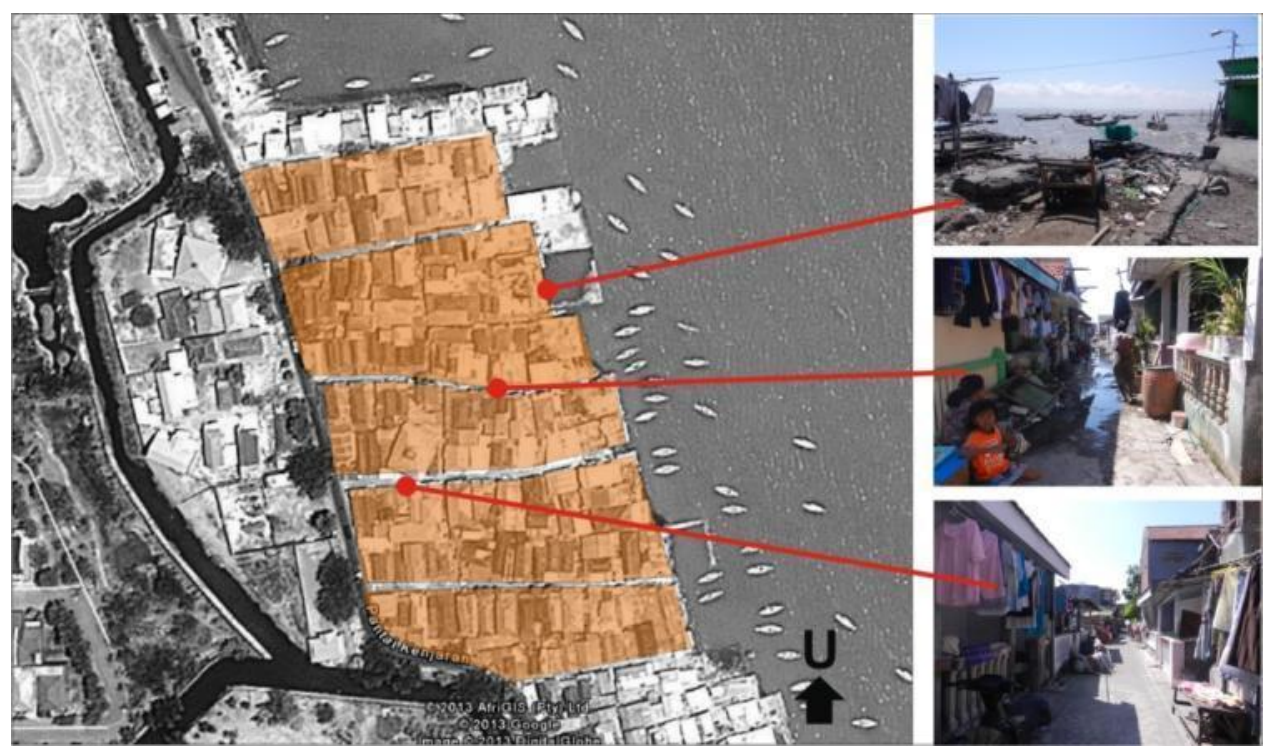

Figure 5. The Case Study Area

Source: map - modified from Google Map, 2013, photos - authors' photographs

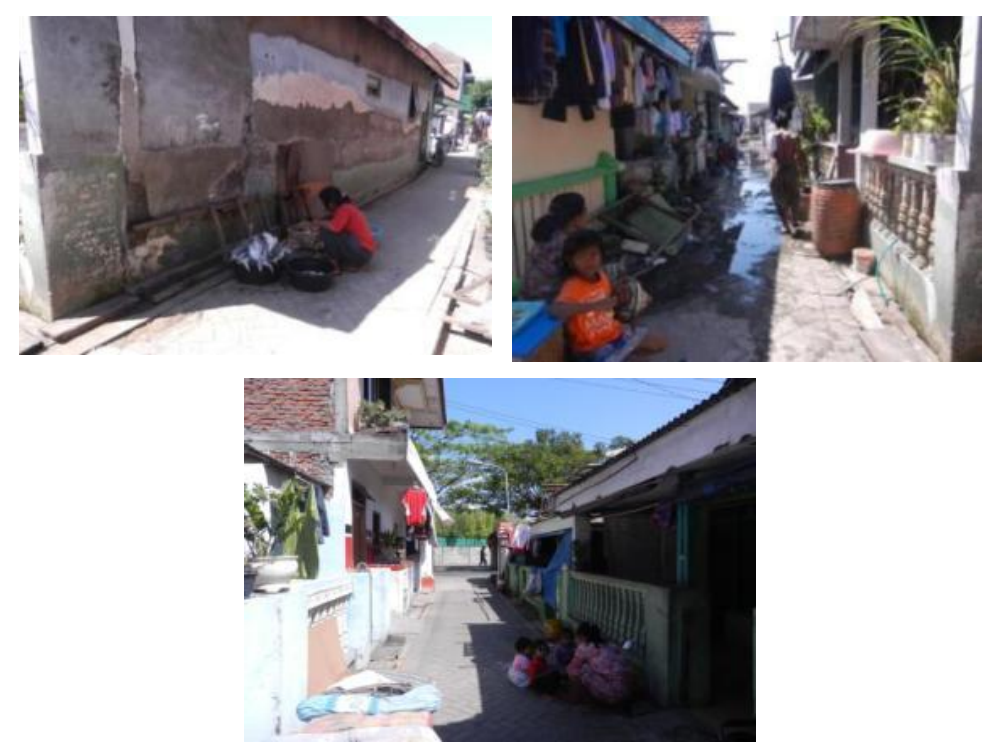

Figure 6. Daily Community Activities in Kampung Kejawan Lor Source: Authors' photographs, 2013

\section{Problems and Potentials}

The informal settlement of Kampung Kejawan Lor has lots of issues regarding open space provision. First thing which have been mention above, is lack of common open space. Secondly is the issue about lack of greenery for open space. Green plantation in this densely settlement is only derived from small amount of plants and 
trees planted by fraction of society. The trees and plantation do not function as a shelter, thus make the open space extremely hot during daytime. The only available vacant lot is owned by the Municipality and at the present condition is occupied with garbage (see Figure 7 left). Furthermore, the pavement which covers the pathways contributes in high temperatures in daytime and flooding since water cannot be directly absorbed by the soil (see Figure 7 right). The existing pathways can be seen in Figure 8.
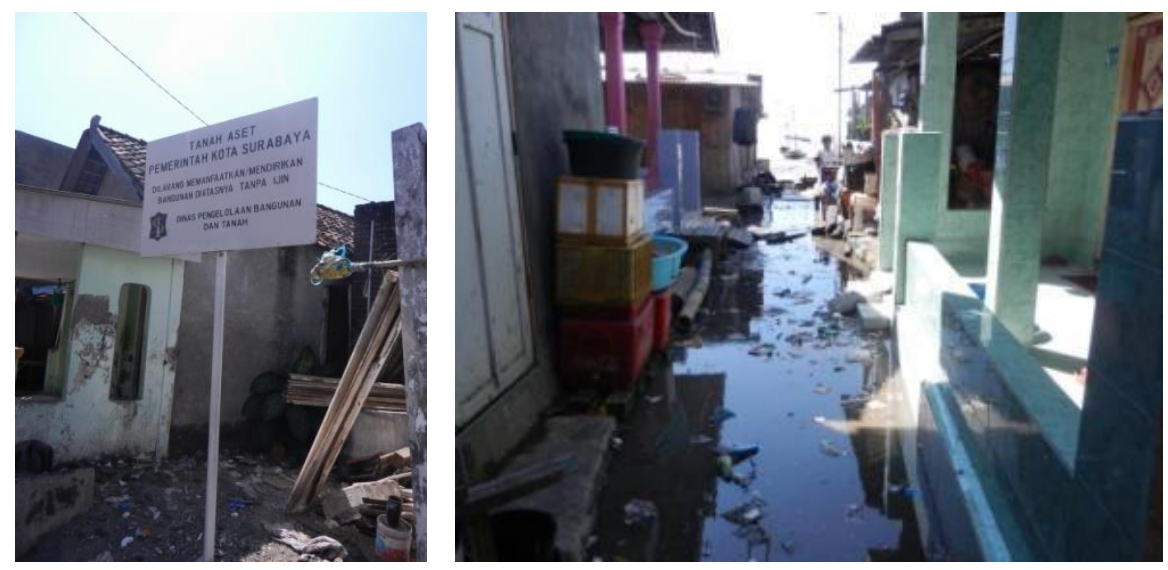

Figure 7. Open Space is Full of Garbage and Suffered from Flooding Source: field survey, 2013
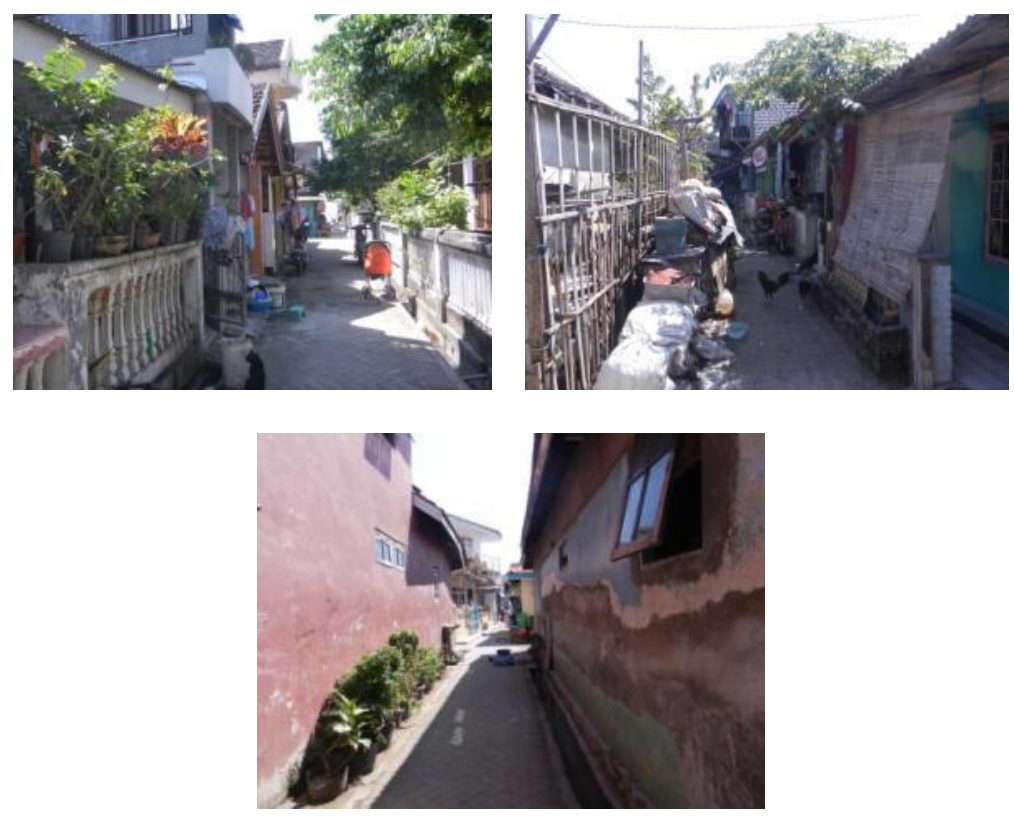

Figure 8. Existing Pathways in Kampung Kejawan Lor Source: field survey, 2013 
Other issues raised from the case study is lack of hygiene which can be seen from trashes inside gutter and scattered in some parts of the settlements. Poor sanitary condition has made the impression of this settlement as a slum area and this is even worsened with the habit of drying clothes in front of their houses (see Figure 9). From the interviews with local residents, it is found that the garbage collection happened because of lack of environmental awareness. This can be seen from their habit of throwing households waste directly into sea. Those households waste then returned back to the settlement when high tide came. Besides, there is no proper waste management system for Kampung Kejawan Lor. Moreover, the community does not have a high level of education. Hence, the awareness for environmental concerns and hygiene are absent.
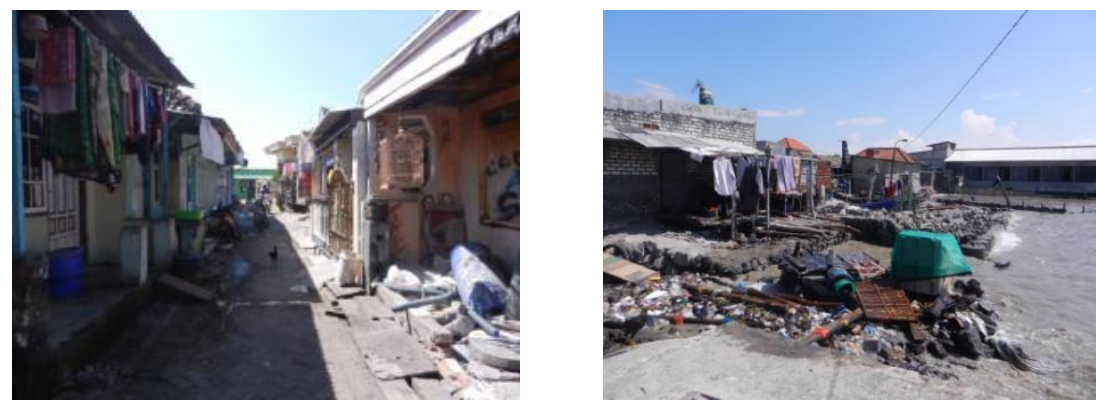

Figure 9. Slum Area of Kampung Kejawan Lor Source: field survey, 2013

\section{Discussion}

From the case study area, many problems regarding green open space were captured. There is no place for the community to have social interaction. The space is not only limited, but almost no vacant and open lot where the community could have space for relaxing and meeting their neighbor, except the pave ways in front of the houses. The houses were also in the poor condition, thus this exasperates the poor living condition. Moreover, household garbage can be found everywhere in the public space area, which makes the neighborhood turns into unhealthy places to live for.

For sure, Kampung Kejawan Lor needs a common public space and greeneries more than it has now. The community needs public open space where they can have opportunities for a pleasant recreation and fresh air to breathe. In order to fulfill these needs, the green space which suitable to their needs could be in the form of vertical garden (see Figure 10), green elements of the houses such as balconies, walls (see Figure 11), and green pave ways. In addition, planning for the public green open space needs to involve the community from the initiation of the project, implementation, and maintenance to ensure the sustainability of the green space. 

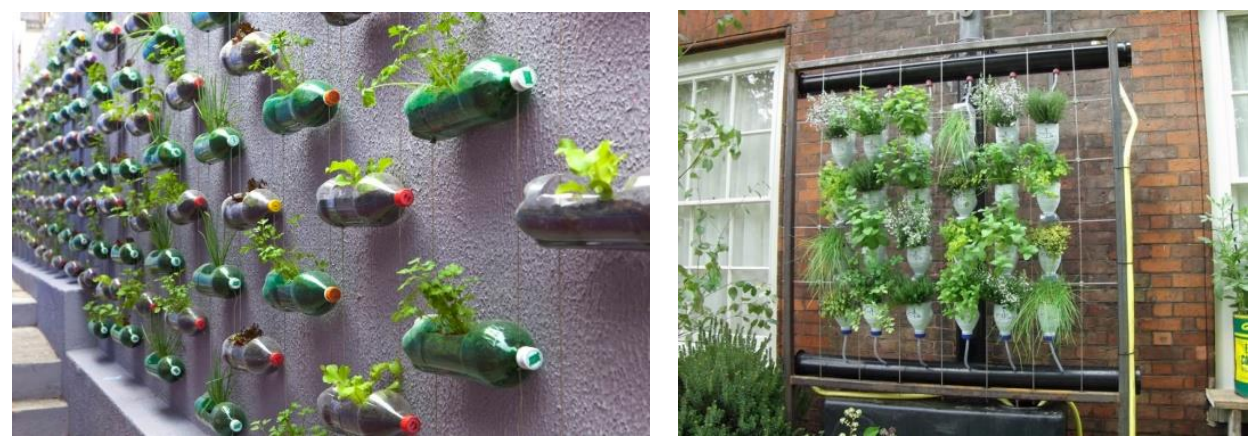

Figure 10. Some Examples of Vertical Garden

Source: http://solaguatierra.blogspot.com/2011/11/el-jardin-vertical-presentacion.html; http://hdgardenspace.blogspot.com/2010/09/we-could-do-this.html

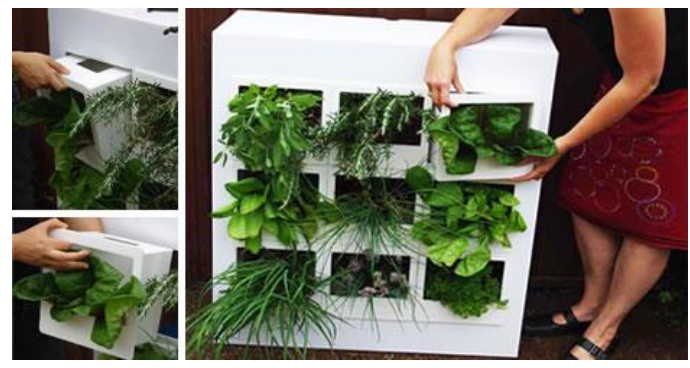

Figure 11. Hollow Block Wall Can be A Place for Plantation

Source:http://futuristicgarden.blogspot.com/ 2010/07/vertical-food-gardens-encourage-urban.html

The walkways where the community uses for social interaction can be designed integrating the needs of greeneries within the neighborhood (see Figure 12). The vacant place can also be activated as urban farming function and public space with local identity for the community.
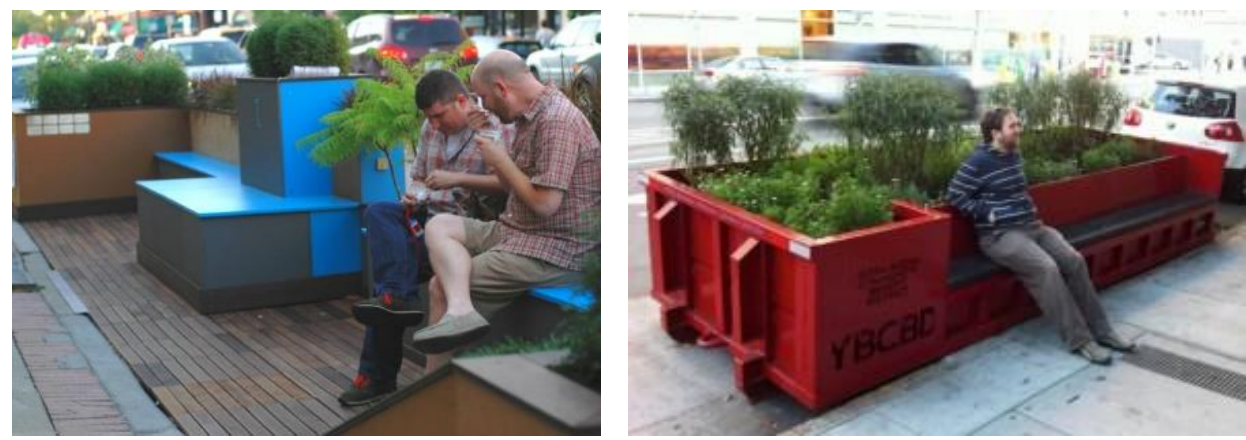

Figure 12. Design for Greeneries Integrated with Sitting Places

Source: http://desantislandscapes.com/landscape-installation/ parkletts-and-pocket-parks/attachment/parklett-2/ 
To sustain this effort, the community needs to form a community organization which is responsible for managing the physical facilities and keeping the environment clean. The household waste should be separated, thus it can be used as recycled products that can give additional income for the community.

\section{CONCLUSIONS}

For the informal settlements of Kejawan Lor, green space is inevitable necessity for the settlers. Green open space can be regarded as the community social and health needs. Green open space has proven its benefit to social function, environmental benefit, and at the end will improve the quality of life of the community. In such limited space, the existence of a park is not only determined by the size or visibility in terms of grounded space. To answer the problems in the case study area, there should be innovative ways to integrate the greeneries in the housing design by putting neighborhood meeting space in front of the houses. The proposed solution may not be the perfect answer for such perplexed problems. Nevertheless, the efforts to improve the quality of life of people should be our concerns towards sustainable living.

\section{REFERENCES}

Arifin, L. S. A., Indrani, H. I. and Luhukay, M. S. (2012), Optimasi Desain Rumah Nelayan Sebagai Rumah Produktif (Home Based Enterprise) Berdasarkan Effisiensi Lahan Terhadap Produktivitas dan Kesehatan (Laporan Penelitian Hibah Unggulan Perguruan Tinggi), Universitas Kristen Petra, Surabaya

Atensitas (2013), Pixel Pocket Park, <http://world-you-like.europa.eu/en/successstories/project-overview/pixel-pocket-park/ (Accessed on 24 May 2013).

Blake, A. (2013), Pocket Parks, <http://depts.washington.edu/open2100/pdf/2_OpenSpaceTypes/Open_Space_Types/pocket_parks.pdf> (Accessed on 27 May 2013).

Di Monte, P. and Gravalos, I. (2011), Estonoesunsolar-Zaragosa, Spain. Observatory of innovative architectural practice in Europe, <http://www.underconstructions.eu/estonoesunsolar-spain-2/> (Accessed on 30 July 2012)

Felasari, S. (2005), Roles Of Community Along Code River Settlement Yogyakarta In Vegetation Planting, Proceeding of Informal Settlements and Affordable Housing Meeting and Conference, page I-24 - I-34, Surabaya 17-18 November 2005, Department of Architecture ITS and the International Council for Research and Innovation in Building and Construction (CIB).

Kirmanto, et al. (2012), Indonesia Green City Development Program: an Urban Reform, $48^{\text {th }}$ ISOCARP Congress 2012, 10-13 September 2012, Perm, Russia.

Kuo, F. E. (2010), Parks and Other Green Environments: Essential Components of a Healthy Human Habitat, Research Series 2010, National Recreation and Park Association.

Lerner, J. (2003), Urban Acupuncture, Rio de Janeiro, Record. 
National Recreation and Park Association. (2013), Creating Mini-parks for Increased Physical Activity, <http://www.nrpa.org> (Accessed on 24 May 2013).

Nicholson-Lord, D. (1987), The Greening of the Cities, Routledge and Kegan Paul, New York.

S. Gairola and Noresah, M.S. (2010), Emerging Trend of Urban Green Space Research and the Implications for Safeguarding Biodiversity: A Viewpoint, Nature and Science, 43-49, <http://www.sciencepub.net/nature/ns0807/06_2710_ns0807_43_49.pdf> (Accessed on 29 July 2013).

Santoso, E. I. (2012), Taman Sayur Organik Perkotaan: Manfaat Ekonomi dan Termal, <http://stage.4archiculture.com/index.php?r=blog/post/view\&id=166> (Accessed on 29 July 2013).

Shirleyana (2013), The Possibility of Converting Available Spaces into Pocket Parks in Urban Settlements in Indonesia, e-JETU, 1, 1-6, Universitas Widya Kartika, Surabaya. 
Shirleyana, Sari: THE POSSIBILITY FOR PUBLIC GREEN OPEN SPACE PROVISION IN INFORMAL

This page intentionally left blank 